Sign Systems Studies 46(1), 2018, 126-142

\title{
Umwelt, Lebenswelt and Dasein seen through the lens of a subjective experience of reality
}

\author{
Zdzisław Wąsik \\ Faculty of English, Adam Mickiewicz University in Poznań, \\ al. Niepodległości 4, 61-874 Poznań, Poland, \\ e-mail: zdzis.wasik@gmail.com
}

\begin{abstract}
Departing from estimations of existential universes of animals (umwelt) and humans (Lebenswelt and Dasein), this paper observes a number of views on the subjective experience, or modelling systems of reality, developed in the philosophy of nature and culture. The first part examines how the semantic relationships of nonhuman and human organisms with their environments are outlined in phenomenology as a study of individual experience from a subject-oriented perspective. Respectively, animals are admitted to have meaningful relations with actual things in observable reality through an outward extension of their bodies, but they are stated to lack direct access to things in themselves and to their various forms of being, because they cannot transcend the imprisonment in their surroundings. In the second part, exposing the mundane background of semiotic phenomenology, the existence modes of animal and human subjects are considered in terms of being-in-the-world as immanence and being-for-the-world as transcendence. Immanent subjects are seen as existing in their environments and transcendent subjects as being able to go beyond their Lebenswelten. In keeping with positively marked or unmarked interpretations of existence and life in the subjective universes of humans and animals, made by other philosophers and psychologists, the author arrives at a conclusion that the extension of the study of reality and the world might enrich the framework of existential semiotics if the organisms' relations to the world they dwell in were considered from the viewpoint of their becoming in the world and the becoming of the world as a result of their interactions.
\end{abstract}

Key words: ecology; existentialism; phenomenology; semiotics; subjectivity

\section{Subjective universes of animals and humans as semiotic spheres}

In the first part of this paper, the terms 'umwelt', introduced by Jakob von Uexküll (1864-1944), a Baltic German biologist and philosopher of nature, and 'Lebenswelt', 
put into use by Edmund Husserl (1859-1938), a German mathematician and philosopher of humanity, are interpreted with regard to animal and human environments on the basis of their terminological applications and interpretation in existentialist phenomenology, philosophy of biology, and biological semiotics (for pertinent details, see Wąsik 2001 and Sonesson 2006; as well as Zlatev 2007, 2009 as to historical and typological outlines of the concept of meaning).

\subsection{The phenomenology of the animal world in the light of biosemiotics}

The term 'umwelt', denoting the 'surrounding world', derives its semantic connotation from Jakob von Uexküll who has investigated how living organisms perceive their environment and how this perception determines their behaviour. Pertaining to the subjective world of an organism, this term was coined by Uexküll in his book Umwelt und Innenwelt der Tiere as early as in 1909. As Kalevi Kull (1999: 390) has remarked, "in his article of 1907 he still uses the term 'Milieu', as different from 'Außenwelt"' (cf. Uexküll 1907). Soon afterwards, in 1920, this framework was enriched with a new term 'Umweltröhre(n)' ['environmental pipe(s)'] introduced in Uexküll's Theoretische Biologie (1926[1920] and 1928/1920/). Moreover, in the second edition of Umwelt und Innenwelt der Tiere (1921[1909]), a complementary term was added, namely, 'Funktionskreis' (rendered in English as 'functional circle' or lately also as 'functional cycle'), as a clue to understanding meaning in biological terms within the umwelt of an organism (cf. Uexküll, Umwelt und Innenwelt der Tiere, 1921[1909]). Accordingly, metaphorically modelled as a "soap bubble", umwelt may be discussed as denoting a particular environment of an animal acting at a given moment in a 'functional circle' (Funktionskreis) consisting of medium, food, enemy or sex (cf. Uexküll, "The theory of meaning", 1982 [1940]: 59-60, especially 71), and Umweltröhren appear to be useful for showing a sequence of all environmental circles that the individual organism has to pass in a stroll throughout its whole life understood as a determined journey. This investigative method of pursuing and reconstructing the journey through invisible worlds is demonstrated in the works of Jakob von Uexküll and Georg Kriszat, Streifzüge durch die Umwelten von Tieren und Menschen. Ein Bilderbuch unsichtbarer Welten (1992/1957/[1934]), and Jakob von Uexküll's Niegeschaute Welten: Die Umwelten meiner Freunde. Ein Erinnerungsbuch (1936).

Having studied the behaviour of organisms which enter into relationships with their environments, Uexküll noticed that animals at all levels - from unicellulars to hominids, as living systems endowed with the so-called Ich-Ton, i.e., a property of subjectivity, rendered as 'ego-quality' in the English translation of the original German terms signifying musical tones - are capable of discerning meanings from 
environmental indicators. According to Uexküll certain objects of the environment can become meaning-carriers, and function as such, when they possess qualities that are significant for the fulfilment of subject-related needs, as, e.g., Weg-Ton ('path-quality'), Wurf-Ton ('throw-quality'), Trink-Ton ('drinking-quality'), FressTon ('eating-quality'), Sitz-Ton ('sitting-quality'), Hindernis-Ton ('obstacle-quality'), Kletter-Ton ('climbing quality'), etc. (Uexküll 1982: 27-31).

\subsection{Interpreting the phenomenology of life-world in terms of the sign-behaviour of human animals}

Another kind of a subjective universe was proposed by Edmund Husserl in phenomenology under the label of 'Lebenswelt', describing the pre-given world in which humans live. The spherical dimension of human surroundings is visible in Husserl's definition provided during his lectures held in Prague in 1935 and Vienna in 1936, under the title Die Krisis der europäischen Wissenschaften und die transzendentale Phänomenologie. Eine Einleitung in die phänomenologische Philosophie, published for the first time in 1954 and translated into English as The Crisis of European Sciences and Transcendental Phenomenology: An Introduction to Phenomenological Philosophy in 1970:

In whatever way we may be conscious of the world as universal horizon, as coherent universe of existing objects, we, each "I-the-man" and all of us together, belong to the world as living with one another in the world; and the world is our world, valid for our consciousness as existing precisely through this "living together". (Husserl 1970[1954]: 108)

In his definition of Lebenswelt, Husserl adheres to a dualistic division between empirical and rational facts insisting upon the separation of the sensible and the intelligible. This split generates the consequence that the conception of one life-world encompasses two distinct worlds, namely the world of nature and the psychic world (Husserl 1970[1954]: 60).

Husserl's theory of the 'rational world' raises the question of how to use the concept of 'world' to designate a discrete domain or closed special regions. It is significant that Husserl links the widespread use of 'world' to the appearance of a special subjectoriented psychology that combines both empiricism and rationalism to generate "a psychophysical anthropology in the rationalistic spirit". A phenomenological concept of world in Husserl's interpretation should not only overcome the hitherto prevailing opposition between empiricism and rationalism, but also have the extent to include simultaneously the spiritual world, the ideals world and the life-world (cf. Husserl 1970[1954]: 62). 
Thus, Husserl's conception of 'life-world' demands a more authentic understanding of subjectivity and objectivity, as far as to live is always to live-in-certainty-ofthe-world. Waking life is being awake to the world, being constantly and directly conscious of the world and oneself as living in the world, actually experiencing [erleben] and actually effecting the ontic certainty of the world. Thereby, world is pregiven in every case in a way in which individual things are given. Still, there exists a fundamental difference between the way we are conscious of the world and the way we are conscious of things or objects (taken in the broadest sense, but still purely in the sense of the life-world), though together the two make up an inseparable unity (cf. Husserl 1970[1954]: 142-143).

It was, however, slightly earlier, in his manuscript from 1890 “Zur Logik der Zeichen (Semiotik)" ['On the logic of signs (semiotics)'], that Husserl (1970/1890/) gave some attention to the origins of sign behaviour. His explanation may be summarized in four statements: firstly, all animals react to phenomena as signs of existentially relevant objects or situations; secondly, when they are able to grasp causal or regular connections between some parts of situations, they usually choose these as signs of the whole; thirdly, when communication occurs with the use of signs it must be preceded by sign consciousness (Zeichenbewusstsein); and, finally, that at further evolutionary stages the users of signs must be aware of regular effects of their intended use(s).

\subsection{The reality of everyday life as an intersubjective world}

On the margin of the presentation of Husserl's Lebenswelt, it should be added that the term 'life-world', used in mundane phenomenology as the translation of the German original, was abandoned by the authors of The Social Construction of Reality, Peter Ludwig Berger (1929-2017), and Thomas Luckmann (1927-2016), in favour of the term "the reality of everyday life" understood as a socially constructed world (cf. Berger, Luckmann 1966: 23). The term was continued in the work of Alfred Schütz (1899-1959), an Austrian philosopher and sociologist, first in the English and then German editions, by Thomas Luckmann (cf. Schütz, Luckmann, Strukturen der Lebenswelt. 1975[1973], following Schütz's Der sinnhafte Aufbau der sozialen Welt. Eine Einleitung in die verstehende Soziologie, 1932).

As Berger and Luckmann (1966: 23) wrote:

The reality of everyday life further presents itself to me as an intersubjective world, a world that I share with others. This intersubjectivity sharply differentiates everyday life from other realities of which I am conscious. I am alone in the world of my dreams, but I know that the world of everyday life is as real to others as it is to myself. Indeed, I cannot exist in everyday life without continually interacting and communicating with others. 
According to the conviction of social constructivists, society is the creator of knowledge, although an individual human being, as an organism, de facto experiences the reality while receiving various kinds of information from the environment. The stock of everyday knowledge is created due to social interactions; this knowledge is, as can be said, following Berger and Luckmann (1966: 19-46), negotiated and approved among particular members of society. An individual can have access to the subjectivity of other individuals. What is more, Berger and Luckmann (1966: 34) argue:

Human expressivity is capable of objectivation, that is, it manifests itself in products of human activity that are available both to their producers and to other men as elements of a common world. Such objectivations serve as more or less enduring indices of the subjective process of their producers, allowing their availability to extend beyond the face-to-face situation in which they can be directly apprehended.

In voice communication, sound waves are objectivated as elements of common world:

A special but crucially important case of objectivation is signification, that is, the human production of signs. A sign may be distinguished from other objectivations by its explicit intention to serve as an index of subjective meanings. To be sure, all objectivations are susceptible of utilization as signs, even though they were not originally produced with this intention. (Berger, Luckmann 1966: 35)

Thus, to sum up, human expressivity is clearly manifested in products accessible both to their creators and to other people. These real objects which are observable and which become symptoms of actions - or their meaning-bearers - were considered by Berger and Luckmann as elements of the common world.

\subsection{Animal symbolicum on the evolutional scale of communication systems}

On reading Husserl's ideas pertaining to the awareness of signs, Ernst Cassirer (18741945) expressed his opinion on the mutual relationships between the sensuous bearer of meaning and the meaning itself in several places of his Philosophie der symbolischen Formen (cf. Cassirer 1955[1923-1929], 1995). However, he had created his humancentred phenomenology of symbolic forms directly under the influence of his contemporary scientific colleague at the University of Hamburg, namely his friend Jakob von Uexküll. As Frederik Stjernfelt pointed out when discussing the topic of simple animals and complex biology, Uexküll had a twofold influence on Cassirer's philosophy. The first influence of Uexküll upon Cassirer was connected with the 
conception of "an Umwelt (surrounding world), determined by its specific Bauplan and the possibility it yields for classes of perceptions and actions" and the second, according to the account of Frederik Stjernfelt (2011: 171), with the definition of man as "the animal symbolicum" (Stjernfelt 2011: 172).

Entering into the epistemology of biology, Cassirer (1962/1944/: 24), in his conclusive work An Essay on Man from 1944, poses the question: "Is it possible to make use of the scheme proposed by Uexküll for a description and characterization of the human world?" Thereafter, he answers it as follows: "Obviously this world forms no exception to those biological rules that govern the life of all the organisms. Yet, in the human world we find a new characteristic which appears to be the distinctive mark of human life ... a third link which we may describe as the symbolic system" (see Cassirer 1962/1944/: 24). As he further explains:

$[\mathrm{M}]$ an lives in a symbolic universe. Language, myth, art, and religion are parts of this universe. [...] Instead of dealing with the things themselves man is in a sense constantly conversing with himself. He has so enveloped himself in linguistic forms, in artistic images, in mythical symbols or religious rites that he cannot see or know anything except by the interpretation of this artificial medium. [...] He lives rather in the midst of imaginary emotions, in hopes and fears, in illusions and disillusions, in his fantasies and dreams. (Cassirer 1962/1944/: 24)

With regard to philosophical anthropology, Cassirer, based on research on the mental capacity of apes, argued that animal behaviour includes only signals, but not symbols. Even when practical imagination and intelligence is attributed to an animal, it is only man who has the power of "a symbolic imagination and intelligence" (Cassirer 1962/1944/: 33). As he furthermore claimed, higher-order apes can communicate symbolically under specific conditions created by humans, and some birds are able to categorize different objects and to learn songs while creating their melodic varieties. However, a two- or three-year-old child not only learns, but also masters its own language. The range of symbolic forms and genres may include zoosemiotic systems, but, on the other end of the evolutionary scale marking the first civilizations of humans, there is the emergence of mathematics and scientific knowledge.

\subsection{On three levels of modelling the mundane reality in the semiotics of nature and culture}

The background of Cassirer's concept of symbolic forms was noticed by Thomas A. Sebeok (orig. Sebők, 1920-2001) in his paper "Von Vico zu Cassirer zu Langer" (cf. 1994[1992]) placing him between the historiosophical thought of Giambattista Vico (1668-1744) and the philosophy of Susanne Langer (1895-1985), pertaining to 
mentalist symbolism in language and art. What is also worth mentioning here is the rapport between Vico and Juri Lotman (1922-1993), the promoter of a textual view of culture as a semiosphere, discussed in Tuuli Raudla's article "Vico and Lotman: poetic meaning creation and primary modelling" (2008).

In conformity with Uexküll's and Cassirer's separation of animal and human universes based on a semiotic opposition between the signs of nature and the symbols of culture while being opposed to the distinction of primary and secondary modelling systems suggested by Lotman, Sebeok postulated the existence of three levels of the modelling of reality, answering the question (posed at the Semiotic Society of America Meeting in 1987): "In what sense is language a 'primary modelling system'?" (cf. Sebeok 1988).

In his theses, first published in 1967 under the title “Тезисы к проблеме 'Искусство в ряду моделирующих систем"' [“The place of art among other modelling systems”], Lotman (2011 [1967]: 250) describes a model as "an analogue of an object of perception that substitutes for it in the process of perception". Accordingly, in his view: "Modelling activity is human activity in creating models. In order that the results of this activity could be taken as analogues of an object, they have to obey certain (intuitively or consciously established) rules of analogy and, therefore, be related to one modelling system or another" (Lotman 2011[1967]: 250). Accordingly, "A modelling system is a structure of elements and rules of their combination, existing in a state of fixed analogy to the whole sphere of the object of perception, cognition, or organization. For this reason, a modelling system may be treated as a language" (Lotman 2011[1967]: 250).

While taking a stand on Lotman's position by posing the question, "In what sense is language a 'primary modelling system'?", Sebeok puts forward his modelling systems theory based on the discrimination between non-verbal communication and verbal systems. At the same time, he mentions that it is very likely that the Homo habilis had the capacity of language without any verbal expression, claiming that: "Solely in the genus Homo have verbal signs emerged. To put it in another way, only hominids possess two mutually sustaining repertoires of signs, the zoosemiotic non-verbal, plus, superimposed, the anthroposemiotic verbal" (Sebeok 1988: 55). According to Sebeok, what the Russo-Estonian semioticians call "primary", i.e., the anthroposemiotic verbal, is "phylogenetically as well as ontogenetically secondary to the nonverbal; and, therefore, what they call 'secondary' is actually a further, tertiary augmentation of the former" (Sebeok 1988: 55).

In his studies on the semiotic self under the title A Sign is Just a Sign, Sebeok postulates three modelling systems of reality (cf. Sebeok 1991[1979]; 1991). Accordingly, following the semioticians of nature and culture, the primary modelling system (PMS) of reality is located on the level of animals possessing the ego-quality which acts through the mediation of effectors and receptors, i.e., on the level of 
indexical symptoms and appealing signals. The secondary modelling system (SMS) involves, in turn, the extralinguistic reality of everyday life construed by the use of verbal means of signification and communication, which occurs as such only in the realm of human organisms. The tertiary modelling system (TMS), which includes the secondary one, is characterized as encompassing the whole semiosphere of language and culture and civilization where the representations of extrasemiotic reality are artificially created in accordance with axiological (value-and-good-oriented) and praxeological (function-and-purpose-oriented) principles.

Describing the triadic relationship between "developmental" stages of an individual organism in terms of anthroposemiosis, Thomas Sebeok and Marcel Danesi have maintained that (1) PMS is "the system that predisposes the human infant to engage in sense-based forms of modelling"; (2) SMS - "the system that subsequently impels the child to engage in extensional and indexical forms of modelling"; and (3) TMS "the system that allows the maturing child to engage in highly abstract (symbolbased) forms of modelling" (Sebeok, Danesi 2000: 10).

\section{Interpreting the being modes of human subjects in terms of existential semiotics}

In the second part of the article, a search for the roots of existential semiotics characterized by the category of Dasein, which is central to the mundane phenomenology of Martin Heidegger (1889-1976), begins with rethinking the layout of the human-centred semiotics developed by Eero Tarasti in the light of philosophers who pay attention to 'existence' as a dwelling in the real world and 'transcendence' as going beyond the concrete reality and starting a trans-mundane journey to other realities through the acts of subjective sign-and-meaning-creation (semiosis). Two of Tarasti's subsequent works published in the last decades, namely, "What is existential semiotics? From theory to application" (2009) and Sein und Schein. Explorations in Existential Semiotics (2015), appear to be most advanced as a theoretical framework for the purposes of detailed consideration.

\subsection{The worldhood of the world through the vantage point of Dasein as being-in-the world}

The existential relationship of the human subject with the world in which he lives should especially be exposed on the basis of Heidegger's works with special reference to Sein und Zeit (1962[1927], "Vom Wesen des Grundes" (1998[1929], and Die Grundbegriffe der Metaphysik: Welt - Endlichkeit - Einsamkeit (1995[1983]). 
As Heidegger noted in 1929, Sein und Zeit constitutes the second of three different approaches to the problem of the world (see Heidegger 1995[1983]: 176-177). The first approach in "Vom Wesen des Grundes" (1998[1929]) deals with the historical development of the word and the concept of world. The second approach, in Sein und Zeit (1926-1927), addresses "the phenomenon of world by interpreting the way in which we at first and for the most part move about in our everyday world" (see Heidegger 1995[1983]: 177). The third one, discussed in its turn in Die Grundbegriffe der Metaphysik: Welt - Endlichkeit (1929-1930), is based on a "comparative examination" of man, animals, plants and stones (see Heidegger 1995[1983]: 177).

What makes Sein und Zeit distinctive is its emphasis on the world not as a concept but as a phenomenon (das Weltphänomen). A phenomenon describes something that becomes "manifest" and "shows itself in itself" (see Heidegger 1962[1927]: 28-29). Thus, the world as a phenomenon should give us the world itself. As Heidegger explains, his attempt was "to provide a preliminary characterization of the phenomenon of world by interpreting the way in which we at first and for the most part move about in our everyday life" (Heidegger 1995[1983]: 177). Following Heidegger's path of reasoning, how he approaches the world from the vantage point of Dasein, as beingin-the-world, we might therefore grasp the phenomenon of the world: "That which is so close and intelligible to us in our everyday dealings is actually and fundamentally remote and unintelligible to us" (Heidegger 1995[1983]: 177).

What Heidegger addresses in his third approach are thus the three concepts, namely 'world', 'finitude', and 'solitude', which form a unity. The discussion of animality must therefore be contextualized as belonging to this broader analysis of metaphysics and the essence of man. Without a doubt, Heidegger's famous tripartite thesis constitutes an attempt to understand the essence of "the other beings which, like man, are also part of the world", with regard to their relationship to and difference from the "having world" that marks man: "[1.] the stone (material object) is wordless; [2.] the animal is poor in world; [3.] man is world-forming” (Heidegger 1995[1983]: 177).

\subsection{Philosophical positions of existential semiotics}

The foundations for a human-centred paradigm of existential semiotics were laid by Tarasti at the 9th Congress of the IASS/AIS, Helsinki-Imatra, 11-17 June 2007. To understand Tarasti's contribution (made public for the first time in 2009 and précised lately in 2015) to the semiotic-existential interpretation of transcendental forms of human subjects who cross the boundaries of their life-world by means of signs and sign-processing activities, one should especially examine the relationship and the difference between the understanding of existentialism in the works of Martin Heidegger and Jean-Paul Sartre (1905-1980). 
The sources and way of thinking of Heidegger and Sartre were completely unrelated. Heidegger's development path departs from that of the forerunners of existentialism, Søren Kierkegaard (1813-1855), made known through Afsluttende uvidenskabelig Efterskrift til de philosophiske Smuler (1941[1846]), and Karl Jaspers (1883-1969), having been acknowledged for Allgemeine Psychopathologie (1962[1946/1913/]). The direction of Sartre's reasoning, expressed in "La transcendance de l'ego: Esquisse d'une description phenomenologique" (1990/1960[1936-1937]) and L'Être et le néant: Essai d’ontologie phénoménologique (1956[1943]), stems from the speculative philosophy of Immanuel Kant (1724-1804), inaugurated in Critik der reinen Vernunft (cf. 1941[1846]) and Georg Wilhelm Friedrich Hegel (1770-1831) resulting from the dissemination of ideas derived from Phänomenologie des Geistes (cf. Hegel 1977/1910/ [1952/1807/]). Therefore, Tarasti proposed to go back to Hegel, the first philosopher who characterized his approach to reality as 'phenomenology' alluding to Kant, but who, unlike Kant, expressed his conviction that phenomena constitute a sufficient basis for a universal science of being.

Having departed from phenomenology as the study of human experience consciously realized by the senses (or lived through) from a subjective or first-person point of view, Tarasti concentrated on rethinking the layouts of human-centred semiotics in the light of selected philosophers who paid attention to the notions, such as, inter alia, 'subject,' 'existence,' 'transcendence', and 'value.' These selected semioticsbased concepts were placed on the philosophical background of such notional categories of existential phenomenology as 'Umwelt', 'Lebenswelt' and 'Dasein'.

The primary point of reference in Tarasti's inquiry that started with the question "What is existential semiotics?" (2009), and was representatively summarized in Sein und Schein (2015), consisted in the categories 'An-sich-sein' ('being-in-itself') and 'Für-sich-sein' ('being-for-itself') discerned by Hegel in his Phänomenologie des Geistes (1977/1910/[1952/1807/]). These categories subsequently turned into subjective and objective being in the philosophy of Kierkegaard (1941[1846]) when he spoke about an individual as an observer of him- or herself or the observed one who was said to be a subject or such an individual who was what he/she was because he/she had become like it.

Sartre, an attentive reader of both Hegel (1977/1910/[1952/1807/]) and Kierkegaard (1941[1846]), referred to Hegelian concepts using the French terms, namely, 'être-ensoi' and 'être-pour-soi. ${ }^{1}$ For Sartre ([1956[1943]), the being as such becomes aware of itself through an act of negation and, when becoming an observer of itself, it shifts its interest into the position of being for itself. Having noticed a lack in its reality, the being begins with the first act of transcendence as far as it strives to fulfil what it lacks.

1 Cf. the original source of citation in Sartre's L'Être et le néant: Essai d'ontologie phénoménologique (1956[1943]: 124-125). 


\subsection{Individual and social being forms of human body in the semiotic phenomenology}

In his studies on Hegel's Phänomenologie des Geistes (1977/1910/[1952/1807/]), Tarasti $(2009,2015)$ was influenced by Jacques Fontanille, one of the main representatives of the Paris School of Semiotics. Following Fontanille's corporeal semiotics after his book Soma et séma. Figures du corps (Fontanille 2004: 22-23), Hegelian categories 'Ansich-sein' and 'Für-sich-sein' were further extended in Tarasti's existential semiotics (cf. Tarasti 2009: 1761-1763; 2015: 22-24) through 'An-mir-sein' and 'Für-mich-sein' ['être-en-moi' ('being-in-myself') and 'etre-pour-moi' ('being-for-myself')].

In his appropriation of Hegelian categories, Fontanille (2004) has presented a distinction between individual and social being forms of human body (soma) in an entirely new phenomenological sense (séma). Accordingly, he has proposed to detach two kinds of body-related meanings for human agents (actants) while separating the body experienced inside of their organism as a flesh, which forms the centre of all physiological and semiotic processes, from the body observed outside of their organism, which shapes their uniqueness and behavioural characteristics.

In fact, Fontanille has proposed a distinction between 'Moi' and 'Soi' as two categories referring to the same acting individual. According to Fontanille (2004: 22 ), the body as a flesh constitutes the totality of the material resistance or impulse to meaning-making processes. The body is thus a sensorial driving support of all organismic experiences. Hence, on the one hand, in Fontanille's (2004: 22-23) view, there is a body that constitutes the identity and directional principle of the flesh, being the carrier of the personal 'me' ('Moi'), and on the other hand, the body that supports the 'self' ('Soi'), constructing itself in a discursive activity. As Fontanille has assumed, the Soi is that part of ourselves, which me, Moi, projects out of itself to create itself in its activity. Likewise, the Moi is that part of ourselves to which the Soi refers when establishing itself. In Tarasti’s interpretation (cf. 2009: 1761): “The Moi provides the So $i$ with impulse and resistance whereby it can become something. In turn, the Soi furnishes the $M o i$ with the reflexivity that it needs to stay within its limits when it changes. The Moi resists and forces the Soi to meet its own alterity." Hence, Moi and So $i$ are to be seen as inseparable.

Although Fontanille departs from the viewpoint of semiotics, being influenced by Algirdas Julien Greimas (1917-1992), the promoter of structural semantics (cf. Greimas, Sémantique structurale: recherche de méthode, 1966; Greimas, Sémiotique et sciences sociales, 1976; and Fontanille, Greimas, Sémiotique des passions: des états de choses aux états d'âme, 1991), his reasoning suits the phenomenological categories of Hegel distinguished in Phänomenologie des Geistes (1977/1910/[1952/1807/]). In accordance with his proposal, a new interpretation of 'An sich' and 'Für sich' is involved, the former corresponding to the bodily ego, and the latter to its stability 
and identity and its aspiration outward, or the Sartrean negation. The Soi functions as a kind of memory of the body or Moi; it yields its form to those traces of tensions and needs that have been inserted in the flesh of the Moi. Anyhow, before pondering which consequences this distinction has to existential semiotics, it is necessary to scrutinize the principles of $M o i$ and Soi as such. Consequently, anything belonging to the category of 'Mich' ('me'), concerns the subject as an individual entity, whereas the concept of 'Sich' ('him-/her-/it-self') has to be reserved for the social aspect of this subject.

When one thinks about the identity and individuality of an organism, one can distinguish in it two aspects: Moi and Soi. In 'me', the subject appears as such, as a bundle of sensations, and in 'himself', 'herself' or 'itself', the subject appears as observed by others or socially determined. These labels, Moi and Soi, connote the existential and social aspects of the subject or, rather, the individual and communitarian sides of the whole self as an investigative object of neosemiotics.

\subsection{Human subjects in existential acts of self-awareness}

After considering the phenomenological scaffolds of Hegel's Phänomenologie des Geistes (1977/1910/[1952/1807/]), Heidegger's Sein und Zeit (1962[1927]) and Die Grundbegriffe der Metaphysik (1995[1983]), Sartre's "La transcendance de l'ego" (1990/1960/[1936-1937] and L'Être et le néant (1956[1943]) as well as Fontanille's Soma et séma (2004), which have influenced Tarasti in elaborating a semiotic model of the corporeal and mental, individual and social existence modes of human subjects in the real world and the transcendence from it into other realities, it is worth enumerating the four modality acts of their self-awareness, reconstituted in a cohesive description (cf. Tarasti 2009: 1766, or 2015: 25):

(1) Being-in-myself - An-mir-sein - être-en-moi in which an individual is willing to appreciate his/her/its existential bodily self-worth;

(2) Being-for-myself - Für-mich-sein - être-pour-moi in which the individual can reflect upon him-/her-/it-self while transcending to the position of an "observer";

(3) Being-in-itself - An-sich-sein - être-en-soi, in turn, in which an individual transcends to probable chances that he/she/it must either actualize or not actualize in society;

(4) Being-for-itself - Für-sich-sein - être-pour-soi in which an individual refers to an actual role he knows how to perform in the existential world of society. 


\section{Life and existence of (non)human organisms as conscious being-in-the-world, being-for-the world and becoming-of- the-world. Concluding remarks and investigative postulates}

Summarizing the similarities and differences between the existential modes of nonhuman and human subjects in terms of their being-in-the-world as immanence, and being-for-the-world as transcendence, one can say that immanent subjects are assumed to exist in or with their environments and transcendent subjects as able to exceed the universe of their (human) life.

A significant dissimilarity between animals and humans, discussed within the framework of existential phenomenology and subject-centred semiotic phenomenology, is noticeable in the meaning of 'life' and 'existence' in terms of conscious awareness of being alive and taking a stand on the existence in the surroundings and existing for the surroundings.

On the margin of this discussion, it has to be admitted that the world of lifeand-death is considered to be common for all systems described (metaphorically?) as 'living' by representatives of anti-speciesism. Yet, following the terminological distinctions encountered in some languages of the world, their users have to be aware that the notions of 'life' and 'death' are restricted only to the world of humans. As a matter of fact, some languages discern the difference between 'living', 'breathing' and 'vegetating' (along with their synonyms) versus 'dying/deceasing, 'decaying/declining', 'rotting/perishing', or 'wilting/withering', and the like.

What is important is the statement that all organisms cohabit (dwell in) the same world Therefore it might be assumed that, considering the relations of organisms to the world they cohabit, their becoming in the world and, subsequently, the becoming of the world is a result of these relations.

\section{References}

Berger, Peter L., Luckmann, Thomas 1966. The Social Construction of Reality. Garden City: Doubleday.

Cassirer, Ernst 1955[1923-1929]. The Philosophy of Symbolic Forms. Vol. I: Language. Vol. II: Mythical Thought. Vol. III: The Phenomenology of Knowledge. (Manheim, Ralph, trans.) New Haven: Yale University Press [Philosophie der symbolischen Formen. Erster Teil. Die Sprache (Zur Phänomenologie der sprachlichen Form), 1923. Zweiter Teil. Das mystische Denken, 1925. Dritter Teil. Phänomenologie der Erkenntnis, 1929. Berlin: Bruno Cassirer.]

- 1962/1944/. An Essay on Man: An Introduction to a Philosophy of Human Culture. (3rd printing.) New Haven: Yale University Press; London: H. Milford/New York: Doubleday and Company; New Haven: Yale University Press; H. London, UK: Milford; Oxford: Oxford University Press. 
- 1995. Symbolische Formen. Zu Band IV (Original manuscript from 1929). In: Krois, John Michael; Schwemmer, Oswald (eds.), Nachgelassene Manuskripte und Texte. Bd 1. Zur Metaphysik der symbolischen Formen 1921-1940. Hamburg: Felix Meiner, 199-258.

Fontanille, Jacques 2004. Soma et séma. Figures du corps. Paris: Maisonneuve et Larose.

Fontanille, Jacques, Greimas, Algirdas J. 1991. Sémiotique des passions: des états de choses aux états d'âme. Paris: Éditions du Seuil.

Greimas, Algirdas J. 1966. Sémantique structurale: recherche de méthode. Paris: Larousse.

- 1976. Sémiotique et sciences sociales. Paris: Éditions du Seuil.

Hegel, Georg Wilhelm Friedrich 1977/1910/[1952/1807/]. Phenomenology of Spirit. (Miller, Arnold V., trans.; Findlay, John Niemeyer, analysis, foreword.) Oxford (etc.): Oxford University Press /Phenomenology of Mind. (Baillie, James Black, trans., intr., notes.) London: George Allen \& Unwin; London: Swan Sonnenschein \& Co.; New York: Macmillan Company./ [System der Wissenschaft. Erster Theil, die Phänomenologie des Geistes. Bamberg, Würzburg: Verlag Joseph Anton Goebhardt /Phänomenologie des Geistes. (Fünfte Auflage. Nach dem Texte der Originalausgabe herausgegeben von Johannes Hoffmeister. Philosophische Bibliothek 114) Hamburg: Felix Meiner Verlag/].

Heidegger, Martin 1962[1927]. Being and Time. (Macquarrie, John; Robinson, Edward, trans.) London: SCM Press [Sein und Zeit. Tübingen: Max Niemeyer].

- 1995[1983]. The Fundamental Concepts of Metaphysics: World, Finitude, Solitude. (McNeil, William H., Walker, Nicholas, trans.) Bloomington: Indiana University Press [Die Grundbegriffe der Metaphysik: Welt - Endlichkeit - Einsamkeit. Frankfurt am Main: Vittorio Klostermann].

- 1998[1929]. On the essence of ground. In: Heidegger, Martin, Pathmarks (McNeil, William H., ed., trans.). Cambridge: Cambridge University Press, 97-135 [Vom Wesen des Grundes. In: Festschrift: Edmund Husserl zum 70. Geburtstag gewidmet ... Halle an der Saale: Max Niemeyer, 71-110 (Ergänzungsband zum Band X des Jahrbuchs für Philosophie und phänomenologische Forschung, herausgegeben von Edmund Husserl)].

Husserl, Edmund 1970/1890/. Zur Logik der Zeichen (Semiotik). In: Husserl, Edmund, Gesammelte Werke, Husserliana. Vol. XII: Philosophie der Arithmetik. Mit ergänzenden Texten (1890-1901). Den Haag: Martinus Nijhoff, 340-373 /manuscript from 1890/.

- 1970[1954]. The Crisis of European Sciences and Transcendental Phenomenology: An Introduction to Phenomenological Philosophy. (Carr, David, trans.) Evanston: Northwestern University Press [Die Krisis der europäischen Wissenschaften und die transzendentale Phänomenologie. Eine Einleitung in die phänomenologische Philosophie. In: Husserliana. Edmund Husserl, Gesammelte Werke. Band VI. Hrsg. Walter Biemel, Den Haag: Martinus Nijhoff].

- 2008[1916-1937]. Die Lebenswelt: Auslegungen der vorgegebenen Welt und ihrer Konstitution: Texte aus dem Nachlass (1916-1937). (Sowa, Rochus, ed.) New York: Julius Springer.

Jaspers, Karl 1962[1946/1913/]. General Psychopathology. (Hoenig, Jan; Hamilton, Marian W., trans.) Manchester: Manchester University Press [Allgemeine Psychopathologie. Ein Leitfaden für Studierende, Ärzte und Psychologen. (Vierte, völlig neu bearbeitete Auflage.) Berlin, Heidelberg: Julius Springer /Erste Auflage, Berlin/].

Kant, Immanuel 1938[1781]. Critique of Pure Reason. (Haywood, Francis, first English trans.) London: W. Pickering [Critik der reinen Vernunft. Riga: Johann Friedrich Hartknoch, (original edition)]. 
Kierkegaard, Søren 1941[1846]. Concluding Unscientific Postscript to Philosophical Fragments. (Swenson, David F.; Lowrie, Walter, trans.) Princeton: Princeton University Press [Afsluttende uvidenskabelig Efterskrift til de philosophiske Smuler. Af Johannes Climacus. Udgivet af S. Kierkegaard (Udkast til indholdsfortegnelse. Trykmanuskript)].

Kull, Kalevi 1999. Biosemiotics in the twentieth century: A view from biology. Semiotica 127(1/4): 385-414.

Lotman, Juri 1977[1974]). Primary and secondary communication-modeling systems. In: Lucid, Daniel Peri (ed., trans.) Soviet Semiotics: An Anthology. Baltimore, London: John Hopkins University Press, 95-98.

- 2011[1967]. The place of art among other modelling systems. (Pern, Tanel, trans.) Sign Systems Studies 39(2/4): 249-270 [Лотман, Юрий Михайлович. Тезисы к проблеме “Искусство в ряду моделирующих систем”. Труды по знаковым системам 3: 130-145].

Raudla, Tuuli 2008. Vico and Lotman: Poetic meaning creation and primary modelling. Sign Systems Studies 36(1): 137-165.

Sartre, Jean-Paul 1956[1943]. Being and Nothingness: An Essay on Phenomenological Ontology. (Barnes, Hazel E., trans., intr.) New York: Philosophical Library [L'Être et le néant : Essai d'ontologie phénoménologique. Paris: Gallimard].

- 1990/1960/[1936-1937]. The Transcendence of the Ego: An Existentialist Theory of Consciousness. (Williams, Forrest., Kirkpatrick. Robert, trans., intr.) New York: Hill and Wang [La transcendance de l'ego: Esquisse d'une description phénoménologique. Recherches philosophiques VI: 85-123].

Schütz, Alfred. 1932. Der sinnhafte Aufbau der sozialen Welt. Eine Einleitung in die verstehende Soziologie. Wien: Julius Springer.

Schütz, Alfred; Luckmann, Thomas 1975[1973]. The Structures of the Life-World. (Zaner, Richard M.; Engelhardt, Jr., H. Tristram, trans.) Evanston: Northwestern University Press. [Strukturen der Lebenswelt. Neuwied, Darmstadt: Luchterhand (Soziologische Texte 82)].

Sebeok, Thomas A. 1988. In what sense is language a "primary modelling system"? In: Sebeok, Thomas A., A Sign Is Just a Sign. Bloomington: Indiana University Press, 49-58.

- 1989/1979/. Neglected figures in the history of semiotic inquiry: Jakob von Uexküll. In: Sebeok, Thomas A. (ed.), The Sign and Its Masters. (2nd ed.) Lanham: University Press of America, 187-207.

- 1991. The semiotic self revisited. In: Sebeok, Thomas A. (ed.), A Sign is Just a Sign. Bloomington, Indianapolis: Indiana University Press, 41-48.

- 1991[1979]. The semiotic self. In: Sebeok, Thomas A. A Sign is Just a Sign. Bloomington, Indianapolis: Indiana University Press, 36-40. / In: Sebeok, Thomas A. The Sign and its Masters. Austin: University of Texas Press (Appendix), 263-267/.

- 1995[1992]. From Vico to Cassirer to Langer. In: Danesi, Marcel (ed.), Giambattista Vico and Anglo-American Science. Philosophy and Writing. Berlin: Mouton de Gruyter, 159-170 [Von Vico zu Cassirer zu Langer. S: European Journal for Semiotic Studies 4 (1/2): 207-222].

Sebeok, Thomas A.; Danesi, Marcel 2000. The Forms of Meaning: Modelling Systems Theory and Semiotic Analysis. Berlin: Mouton de Gruyter.

Sonesson, Göran. 2006. The meaning of meaning in biology and cognitive science. Sign Systems Studies 34(1):135-214.

Stjernfelt, Frederik 2011. Simple animals and complex biology: Von Uexküll's twofold influence on Cassirer's philosophy. Synthese 179(1): 169-186. 
Tarasti, Eero 2000. Existential Semiotics. Bloomington, Indianapolis: Indiana University Press.

- 2009. What is existential semiotics? From theory to application. In: Tarasti, Eero (ed.), Communication: Understanding/Misunderstanding. Imatra: International Semiotics Institute; Helsinki: Semiotic Society of Finland, 1755-1772.

- 2015. Sein und Schein. Explorations in Existential Semiotics. Berlin, Boston: De Gruyter Mouton.

Uexküll, Jakob von 1907. Die Umrisse einer kommenden Weltanschauung. Die neue Rundschau 18: $641-661$.

- 1921/1909/. Umwelt und Innenwelt der Tiere. (Zweite vermehrte und verbesserte Auflage.) Berlin: Julius Springer.

- 1926[1920]. Theoretical Biology. (Mackinnon, Doris L., trans.) New York: Harcourt, Brace \& Co. [Theoretische Biologie. Berlin: Verlag von Gebrüder Paetel].

- 1928/1920/. Theoretische Biologie. (Zweite gänzlich neu bearbeitete Auflage.) Berlin: Julius Springer. /Berlin: Verlag von Gebrüder Paetel/.

- 1936. Niegeschaute Welten: Die Umwelten meiner Freunde. Ein Erinnerungsbuch. Berlin: S. Fischer.

- 1982[1940]. The theory of meaning. (Stone, Barry; Weiner, Herbert, trans.) Semiotica 42(1): 25-82. [Bedeutungslehre. Leipzig: Verlag von Johann Ambrosius Barth (BIOS. Abhandlungen zur theoretischen Biologie und ihrer Geschichte, sowie zur Philosophie der organischen Naturwissenschaften. Band X)].

Uexküll, Jakob von; Kriszat, Georg 1992/1957/[1934]. A stroll through the world of animals and men: A picture book of invisible worlds. (Schiller, Claire H., trans.) Reprint. Semiotica 89(4): 319-391. /In: Schiller, Claire H. (ed.), Instinctive Behavior. The Development of a Modern Concept. New York: International Universities Press, 5-80 [Streifzüge durch die Umwelten von Tieren und Menschen. Ein Bilderbuch unsichtbarer Welten. Berlin: Julius Springer (Sammlung: Verständliche Wissenschaft 21)].

Wąsik, Zdzisław 2001. On the biological concept of subjective significance: A link between the semiotics of nature and the semiotics of culture. Sign Systems Studies 29(1): 83-106.

Zlatev, Jordan 2007. Embodiment, language and mimesis. In: Ziemke, Tom; Zlatev, Jordan, Franck, Roslyn M. (eds.), Body, Language, Mind. Vol 1: Embodiment. Berlin, New York Mouton de Gruyter, 297-337.

- 2009. The semiotic hierarchy: Life, consciousness, signs and language. Cognitive Semiotics 4: 169-200.

\section{Умвельт, Lebenswelt и Dasein сквозь призму субъективного опыта действительности}

Исходя из оценок экзистенциальных миров животных (умвельт) и людей (Lebenswelt и Dasein), в настоящей статье рассматриваются разные точки зрения на субъективный опыт, разные моделирующие системы реальности, разработанные в философии культуры и природы. В первой части исследуется, как семантические связи со средой человеческих организмов и не-людей (non-humans) очерчены в феноменологии субъектно ориентированных исследованиях индивидуального опыта. У животных отмечаются значимые контакты с внешней реальностью посредством их тела, но так 
как они закованы в своем теле, то они не могут постичь самих вещей и их разных форм проявления. Во второй части статьи эксплицируется повседневный фон семиотической феноменологии и рассматриваются способы существования животных и человеческих субъектов в терминах трансцендентности как «бытия-в-мире» и «бытия-для-мира». Имманентные субъекты существуют в своей среде, а трансцендентные способны выйти из своего жизненного мира. В соответствии с положительно маркированными или немаркированными интерпретациями существования и жизни в субъективных мирах людей и животных, отмеченных другими психологами и философами, автор приходит к выводу, что расширение поля исследования реальности может обогатить экзистенциальную семиотику, если бы связи организмов с миром рассматривались бы с точки зрения возникновения их мира, а возникновение их мира - как результат взаимодействия разных организмов.

\section{Omailm, Lebenswelt ja Dasein läbi tegelikkkuse subjektiivse kogemise prisma}

Lähtudes hinnangutest loomade (omailm) ja inimeste (Lebenswelt ja Dasein) eksistentsiaalsetele universumitele, käsitletakse käesolevas artiklis mitmeid vaateid subjektiivsele kogemusele ehk loodus- ja kultuurifilosoofias välja töötatud tegelikkust modelleerivatele süsteemidele. Esimeses osas uuritakse, kuidas mitteinimeste ja inimorganismide semantilised suhted nende keskkonnaga on visandatud fenomenoloogias kui individuaalse kogemuse uurimises subjektile orienteeritud vaatevinklist. Loomadel omakorda mööndakse olevat tähendusrikkad suhted tegelike asjadega vaadeldavas reaalsuses nende kehade väliste laienduste kaudu, ent väidetakse, et neil puudub otsene ligipääs asjadele iseeneses ja nende mitmesugustele esinemisvormidele, sest nad ei suuda ületada vangistatust neid ümbritsevasse. Teises osas, milles tuuakse esile semiootilise fenomenoloogia argine taust, vaadeldakse loom- ja inimsubjektide eksisteerimise viise 'maailmas olemise' kui immanentsuse ja 'maailma jaoks olemise' kui transtsendentsuse terminites. Immanentsed subjektid leitakse eksisteerivat oma keskkonnas, ja transtsendentsed subjektid osutuvad võimelisteks oma eluilmast väljapoole liikuma. Kooskõlas eksistentsi ja elu positiivselt markeeritud või markeerimata tõlgendusega inimeste ja loomade subjektiivsetes universumites, mida on teinud teised filosoofid ja psühholoogid, jõuab autor järeldusele, et reaalsuse ja maalma uurimise laiendamine võiks rikastada eksistentsiaalse semiootika raamistikku, kui organismide sidemeid maailmaga, millest nad elavad, vaadeldaks nende maailma tekkimise vaatepunktist ja maailma tekkimist nende omavahelise vastastikmõju tulemusena. 